\title{
THE WIRE-TAPPING CONTROVERSY: A SYMPTOM OF THE TIMES
}

\begin{abstract}
A Of THE WIRE-TAPPING controversy is but one facet of the large problem of accommodating the often antithetical demands of individual liberty and public welfare, ${ }^{1}$ it affords an insight into the nature and direction of its resolution. ${ }^{2}$ The recent wire-tapping case of United States v. Sullivan, ${ }^{3}$ then, is not without a certain broad significance.

In that case, the defendant, charged with violation of the Narcotics Act, ${ }^{4}$ moved to suppress evidence discovered on his premises pursuant to a search warrant which allegedly had been illegally issued. In support of this allegation, the defendant relied on the admitted fact that
\end{abstract}

${ }^{2}$ In support of legalizing strong wire-tap measures it is argued that to counterbalance the benefits of technology available to law-breakers, law enforcement officers should be empowered to secure evidence through wire-tapping; that such a privilege would be used only against the guilty-for detection of espionage, sabotage, treason, and possibly kidnapping; that it can in no way harm the innocent; and that it does not violate any civil rights. On the other hand, it is argued that wire-tapping cannot be limited to use against the guilty only; that the possible abuses are serious in that too much power would be placed in the hands of a few; and that democracy must sometimes forego efficiency in order to preserve liberty. The Fourth Amendment itself is a bar to quick and efficient action by law enforcement officers; but self-denial on the part of the government is an essential characteristic of any frec socicty. Sec generally Wire Tapping-The Right of Privacy Versus the Public Interest, $40 \mathrm{~J}$. Crim. L. \& Criminolocy 476 (1949); Brownell, The Public Security and WireTapping, 39 CoRnell L.Q. I95 (1954); Westin, The Wire-Tapping Problent: An Analysis and a Legislative Proposal, 52 CoL. L. Rev. 165 (1952); Rosenzweig, The Law of Wire-Tapping, 32 CORNELL L.Q. 514 (1947); Rogers, The Case for WireTapping, 63 YALE L.J. 792 (1954); Donnelly, Comments and Caveats on the WireTapping Controversy, 63 YALE L.J. 799 (1954); BARTH, THE LOYALTY of FREE MEN (1951); Berger, Tapping the Wires, The New Yorker, June 18, 1938; The Hot Wire-Tapping Debate; The Case for, and a Hard-Hitting Argument Against It, Newsweek, Jan. II, I954, p. 20; Wire-Tapping: The Pros and Cons, N.Y. Times Mag., Nov. 29, 1953.

${ }^{2}$ The storm that rages about wire-tapping is at most a reflection of general attitudes towards a system of "ordered liberty." The same elements are present in the debate that now waxes over communist subversion, academic freedoin, "McCarthyism," and many others. See, e.g., McCarthyism, Pro and Con, U.S. News and World Report, Dec. 4, 1953, p. 106; Report on Academic Freedom, 13 LAw. Guild Rev. 30 (1953); Simmons, Democracy and Communism, 27 PHIL. L.J. 831 (1952); Buckley and Bozell, Book Review, America, May 15, 1954, p. 191; Neff, Retreat from Heresy, Science Monthly, Jan. 1954, p. 19; Braden, Tutrmoil in the State Department, U.S. News and World Report, Apr. 9, 1954, p. 30.

${ }^{3} 116$ F.Supp. 480 (D.D.C. 1954).

${ }_{3} 8$ STAT. 785 (1914), 26 U.S.C. \$§ $2550-2604$ (1946). 
the warrant had been issued on the basis of information disclosed in a monitored telephone conversation in which an informer had made arrangements with defendant for the purchase of narcotics. The court denied defendant's motion, however, pointing out that since the informer knew of, and consented to, the eavesdropping, it did not constitute wire-tapping within the prohibition of Section 605 of the Federal Communications Act. ${ }^{5}$ Interception, the court ruled, includes only those instances of wire-tapping and recordation both made without the knowledge and divulged without the consent of either party to the conversation.

Section 605 appears to be an outgrowth of the decision in United States v. Olmstead ${ }^{6}$ where a divided court held that wire-tapping does not contravene the Fourth Amendment's proscription of unlawful search and seizure. ${ }^{7}$ The majority reasoned that one who installs a telephone with connecting wires impliedly intends to project his voice to those outside, and that messages, while passing through wires outside his premises are not within the protection of the Fourth Amendment. ${ }^{8}$ It was the vigorous dissents of Messrs. Holmes and Brandeis, ${ }^{9}$ however,

${ }^{5} 48$ STAT. 1 103 (1934), 47 U.S.C. $§ 605$ (1946). For a brief discussion of this section see Note, Wire-Tapping and Law Enforcement, 53 HARv. L. REv. 863 (1940).

${ }^{\circ} 27$ U.S. $43^{8}$ (1928) (Butler, Stone, Holmes and Brandeis, JJ. dissented). The defendants moved to suppress evidence obtained by wire-tapping without trespassing upon defendants' property. Motion was denied in the trial court, 7 F.2d 756 (W.D. Wash. 1925), aff'd, 19 F.2d 842 (9th Cir. 1927), cert. denied, 275 U.S. 557 (1927).

${ }^{7}$ U.S. Const. AMEND. IV: "The right of the people to be secure in their persons, houses, papers, and effects against unreasonable searches and seizures, shall not be violated, and no Warrants shall issue, but upon probable cause, supported by Oath or affirmation, and particularly describing the place to be searched, and the persons or things to be seized."

${ }_{277}$ U.S. 438,466 (1928).

${ }^{\circ}$ In his dissent, Brandeis, J. said: "When the Fourth and Fifth Amendments were adopted, 'the form that evil had theretofore taken,' had been necessarily simple. Force and violence were then the only means known to man by which a Government could directly effect self-incrimination. It could compel the individual to testify-a compulsion effected, if need be, by torture. It could secure possession of his papers and other articles incident to his private life-a seizure effected, if need be, by breaking and entry. Protection against such invasion of the 'sanctities of a man's home and the privacies of life' was provided in the Fourth and Fifth Amendments by specific language. Boyd v. United States, I16 U.S. 616,630 [1886]. But time works changes, brings into existence new conditions and purposes.' Subtler and more farreaching means of invading privacy have become available to the Government. Discovery and invention have made it possible for the Government, by means far more effective than stretching upon the rack, to obtain disclosure in court of what is whispered in the closet.

"Moreover, in the application of a constitution, our contemplation cannot be only of what has been but of what may be.' The progress of science in furnishing the Government with means of espionage is not likely to stop with wire-tapping. Ways may 
that evoked greater response, and, in I934, as if in protest to the Olmstead decision, Congress enacted the Federal Communications Act, ${ }^{10}$ Section 605 of which provides, in part:

... no person, not being authorized by the sender, shall intercept any communication and divulge or publish the existence, contents, substance ... or meaning of such communication to any person. ${ }^{11}$

The early application of this section was strict. Its language was first construed to prohibit the introduction in federal courts of evidence obtained by wire-tapping. ${ }^{12}$ Subsequently, this ban was extended to evidence traceable to "leads" obtained by wire-tapping ${ }^{13}$ and to evidence disclosed by the interception of intrastate messages. ${ }^{14}$ Regarding early

some day be developed by which the Government, without removing papers from secret drawers, can reproduce them in court, and by which it will be enabled to expose to a jury the most intimate occurrences of the home. Advances in the psychic and related sciences may bring means of exploring unexpressed beliefs, thoughts and emotions. 'That places the liberty of every man in the hands of every petty officer' was said by James Otis of much lesser intrusions than these. To Lord Camden, a far slighter intrusion seemed 'subversive of all the comforts of socicty.' Can it be that the Constitution affords no protection against such invasions of individual security?" 277 U.S. $43^{8}, 473-474$ (1928).

${ }^{10}$ Note, however, that a bill expressly designed to negative the result of the Olmstead case failed to pass. H.R. 5416, 7 Ist Cong., Ist Sess. (1929); see Notes, 27 Mich. L. Rev. 78 (1929), I3 MiNN. L. Rev. 58 (1928); see also The Supreme Court and Unreasonable Searches, 38 YALE L.J. 77 (1928).

${ }^{11} 48$ STAT. 1103 (1934), 47 U.S.C. $\$ 605$ (1946). For the thesis that Section 605 was not directed at wire-tapping, however, sec 25 MinN. L. REv. 382 (I94I) 34 ILL. L. REV. $75^{8}$ (1940).

${ }^{12}$ In Nardone v. United States, 302 U.S. 379 (1937), petitioncrs were tried and convicted on several counts of smuggling, possession and concealment, and conspiracy to smuggle and conceal alcohol. A vital part of the Government's evidence consisted of testimony by federal officers as to the substance of certain communications of the defendants which were overheard by tapping telephone wires. The Government contended that Congress did not intend Section $60_{5}$ to prohibit wire-tapping for cvidence. The court, however, ruled that the phrases "no person," and "any person" were inclusive of law enforcement officers as well as private citizens.

${ }^{13}$ Nardone v. United States, 308 U.S. 338 (1939) (Nardone II).' The fincts in Nardone II were substantially the same as those in Nardone $I$, note 12 supra. Section 605 was ruled applicable, by implication, to evidence procured through the use of knowledge gained through tapped telephone conversations. Frankfurter, J. called such evidence "fruit of the poisonous tree," and the majority ruled out the "fruit" as firmly as it had ruled out direct wire-tap evidence.

${ }^{14}$ Weiss v. United States, 308 U.S. 321 (1939). Here the petitioners were indicted for using and conspiring to use the mails for fraudulent purposes. The Government, by means of a wire-tapping and recording device, had made manuscripts of various incriminating conversations of the defendants. The manuscripts were slown to one of the defendants, and he thereupon agreed to testify for the prosecution. His 
decisions, it has been said that the Supreme Court construed Section 605 as embodying a Congressional decision to insure the citizen's non-constitutional privacy and, in effect, poured the Fourth Amendment into the Federal Communications Act. ${ }^{15}$

A countertendency, however, is discernible in more recent decisions. The bellwether was United States v. Yee Ping Jong ${ }^{\mathbf{1 6}}$ in which the mechanical or electrical recordation of a conversation with the consent or knowledge of one of the parties was held not to "intercept" a communication within the purview of the Act. ${ }^{17}$ This trend was temporarily arrested in United States $v$. Polakoff, ${ }^{18}$ in which Judge Learned Hand, returning to a more inclusive interpretation of Section 605 , ruled that evidence obtained through an extension telephone with the knowledge or consent of one of the parties to the conversation was inadmissible in federal court. Judge Hand, in rejecting the Yee Ping Jong rule, concluded that all significance to the Section 605 privilege would be denied by holding that because one party had originated the call he had the power to surrender the other's privilege. ${ }^{19}$ This decision was based, not upon the Yee Ping Jong concept of "intercept," but rather upon the premise that the word "sender," as used in the statute, applied to both parties to a telephone conversation, and that unless both parties consented to the interception, the statutory ban applied.

The Sullivan case, however, in rejecting the respectable precedent afforded by the Polakoff decision, reverted to the Yee Ping Jong line of decisions which had since gradually been extended to exclude various penumbral areas of the wire-tapping controversy from the purview of Section 605. Thus, in Goldman v. United States, ${ }^{20}$ the use of a detecta-

testimony consisted in part of reading the manuscripts. In addition, the manuscripts themselves were offered in evidence, and they, along with testimony, were admitted by the trial court. Their admission was upheld by the circuit court of appeals, Io3 F.2d 348 ( $2 \mathrm{~d}$ Cir. 1939), but the Supreme Court reversed, holding that there is nothing in Section 605 limiting its scope to interstate commerce, as the Government had contended.

${ }^{15}$ See Westin, op. cit. supra note 1 , at 177 .

1026 F.Supp. 69 (W.D. Pa. I939).

${ }^{17}$ The interpretation rests upon the definition found in Webster's New International Dictionary (2d ed. 1948): "To take or seize by the way or before arrival at the destined place." Accord, United States v. Lewis, 87 F.Supp. 970 (D.D.C. I950). However, in United States v. Polakoff, I I2 F.2d 888, 889 (2d Cir. I940), note I 8 infra, it was held that "The statute . . speaks of 'interceptions' and anyone intercepts a message to whose intervention as a listener the communicants do not consent. . .." See Note, What Constitutes Wire-Tapping, 45 ILL. L. REv. 689 (1950).

${ }^{18}$ I 12 F.2d 888 (2d Cir. 1940). ${ }^{19} I d$. at 889.

${ }^{20} 316$ U.S. 129 (1942). Here the petitioners were indicted for conspiracy to violate Section 29(b) (5) of the Bankruptcy Act. Prior to the trial defendants moved to suppress evidence which had been obtained by means of a detectaphone placed on a 
phone on the wall of an office in which a member of an alleged conspiracy was engaged in telephone conversations was held not to constitute an interception. And in United States v. Lewis, ${ }^{21}$ the district court held, as did the court in the Sullivan case, that evidence procured by means of a monitored telephone conversation was admissible since one of the parties to the conversation had consented to its divulgence.

Nor does this line of cases represent the only area in which the relaxation of the strictures against wire-tapping has become apparent. In Swartz v. Texas ${ }^{22}$ it was held that it is for each state to determine whether evidence obtained by wire-tapping will be admissible in its own courts. This decision has been said to reflect the development of a more rigorous bloc in the Supreme Court tending toward the view that wire-tapping is not repugnant to our "concept of fair play and fundamental rights. 323

To be sure, the tendency toward de-emphasizing individual liberty in the name of public welfare lends itself to facile rationalization in these times. ${ }^{24}$ But what are its limits? Although the interests of na-

wall in a room adjoining the petitioners.' The motion was denied, and the evidence admitted. On appeal, the Supreme Court affirmed the decision, ruling that "interception" within the meaning of the Federal Communications Act, prohibiting interception by wire or radio, indicates taking or seizure by the way or before arrival at the destined place, and does not ordinarily connote obtaining of what is to be sent before, or at the moment, it comes into the possession of the intended receiver. 316 U.S. 129,134 (1942); of. Irvine v. California, 347 U.S. 128 (1954).

${ }_{21} 87$ F.Supp. 970 (D.D.C. 1950). Defendant's motion to exclude evidence obtained through recordation of a telephone conversation with the consent of only one of the parties concerned was denied. The decision was reversed on other grounds, and the Court's ruling as to the wire-tapping was not challenged. Lewis v. United States, I 84 F.2d 394 (D.C. Cir. 1950).

${ }_{22} 344$ U.S. $199(1952)$. In this case state officers set up an induction coil which enabled an operator to overhear and simultaneously record the conversation between the petitioner and the consenting party. It was held, (at 202): "Where a state has carefully legislated so as not to render inadmissible evidence obtained and sought to be divulged in violation of the laws of the United States, this Court will not extend by implication the statute of the United States so as to invalidate the specific language of the state statute."

${ }^{23}$ See note, Criminal Law-Admissibility in State Courts of Wire-Tap Evidence Obtained in Violation of the Federal Communications Act, 19 BRookLYN L. REv. 314, 316 (1953).

24 E.g., although President Roosevelt purportedly authorized war-time wire-tapping, he expressed these sentiments to Representative Eliot: "As an instrument for oppression of free citizens, I can think of none worse than indiscriminate wire-tapping . . . my own personal ... view is close to that of Justice Holmes. ..." Hearings Before Subcommittee No. I of the Committee on the Judiciary on H.R. 2266 and H.R. 3090, 77th Cong., ist Sess. 257 (1941). See generally Emerson and Helfeld, Loyalty Among Government Employees, 58 Yale L.J. 7 I (1948); Note, 2 Stan. L. REv. 744, 750, n. 42 (1950). 
tional security might well be furthered by a relaxation of the existing strictures against the use of wire-tapped evidence, ${ }^{25}$ it is patent that patriotic zeal must be tempered with caution where fundamental democratic values may be affected. There are those who maintain that the trend toward indiscriminate use of wire-tapping has already progressed beyond safe limits, and their concern has been echoed by Mr. Justice Douglas who, dissenting in On Lee v. United States, ${ }^{26}$ confessed:

I now more fully appreciate the vice of the practices spawned by Olmstead and Goldman. Reflection on them has brought new insight to me. I now feel that I was wrong in the Goldman case. $^{27}$

Although the dangers and uncertainties of today add some element of reason to the cause of those who espouse security at all costs, Congress and the courts, while pondering upon a solution to the wiretapping problem, would do well to reflect upon the words of $\mathrm{Mr}$. Justice Brandeis who, dissenting in the Olmstead case, warned:

Experience should teach us to be on our guard to protect liberty when the government's purposes are beneficient.... The greatest dangers to liberty lurk in insidious encroachment by men of zeal, well-meaning but without understanding. ${ }^{28}$

WILLIAM GRIGG

In I93r, J. Edgar Hoover, chief of the Federal Bureau of Investigation, testified as follows:

Mr. Tinkham: "Is any of your appropriation spent for wire-tapping?"

Mr. Hoover: "No, sir. We have a very definite rule in the bureau that any employee engaging in wire-tapping will be dismissed from the service of the bureau."

Mr. Tinkham: "I am very much pleased that that is so."

Mr. Hoover: "While it may not be illegal, I think it is unethical, and it is not permitted under the regulations by the Attorney General."

Hearings Before the House Committee on Expenditures in the Executive Departments, .7 Ist Cong., 3 d Sess. 26 (1931).

Yet in 1941, Hoover felt that ". . . wire tapping should not be permitted except as to such crimes as I have described, and even then in such a limited group of cases only under strict supervision of higher authority exercised separately in respect to each specific instance. In the group of cases I have in mind, such as espionage, sabotage, kidnapping, and extortion, wire-tapping is an investigative function of considerable importance." No. I of the Committee on the Judiciary on H.R. 2266 and H.R. 3099, 77th Cong., 1st Sess. 112 (1941).

${ }^{25}$ For legislative proposals, see Brownell, op. cit. supra note $\mathrm{r}$; Westin, op. cit. supra note I.

20343 U.S. 747 (1952).

${ }^{27} I d$. at 762 .

${ }_{28}^{28}$ U.S. 438,479 (1928); note 6 supra. 